\title{
Does Language Matter? The Impact of Language of Instruction on Study Abroad Outcomes
}

\author{
Emily Mohajeri Norris
}

\section{Michael Stein berg IES Abroad}

The study abroad landscape for American students has changed dramatically from its origins in the 1920s, when programs were designed primarily for foreign language majors to spend their junior year abroad (Brown, 1983). While foreign language programs continued to dominate the offerings into the 1970s, since then study abroad has become a part of the undergraduate experience for a far broader range of students, from all majors. Of the 223,534 Americans studying abroad in 2005-06, the Institute of International Education (2008) reports in Open Doors 2007 that only 7.8\% were foreign language majors. The study of second languages, whether the primary focus of a program or one of many components, is still common in programs taught in non-English-speaking countries, and usually a feature of programs lasting a semester or more. However, short-term programs offered exclusively or primarily in English by U.S. higher education institutions or study abroad providers allow American students to study in locations without requiring foreign language proficiency.

Research on motivations that prompt American students to study abroad has revealed that students may have motivations equal to or more important than foreign language gain, including acquiring cultural knowledge and the opportunity to travel (Carlson, Burn, Useem, \& Yahimowicz, 1990; King and Young, 1994; Koestler, 1986; Opper, Teichler, \& Carlson, 1990). The results of institutional surveys and dissertation surveys support these findings, that second language acquisition was not the primary study abroad goal of the surveyed population (Peterson, 2003; LaFranchi, 2003). This trend is likely to continue. The January 2008 edition of studentPOLL revealed that of the $55 \%$ of high school seniors who indicated plans to study abroad during their college education, only $9 \%$ listed learning a different language as their primary objective for studying abroad (Bartini, Green, \& Heisel, 2008). 
While opportunities for and motivations to study abroad have evolved, second language acquisition and exposure to a second language have remained a central characteristic of education abroad. According to Open Doors 2007, well over two-thirds of Americans studying abroad go to non-English-speaking countries. The January 2008 studentPOLL results indicate that $92 \%$ of high school seniors believe that study abroad programs are the best way to learn or improve in a second language.

Study abroad is a holistic educational experience that affords participants opportunities to develop new academic interests, participate in academic internships, establish friendships with host country nationals, explore a new culture, expand their worldview and sense of self, as well as improve their target language skills. This article aims to demonstrate that the full range of study abroad language environment models all provide valuable experiences with lasting longitudinal benefits - some of which are common to all three models and others that are unique to each model.

\section{Literature Review}

The vast majority of research on the impact of study abroad focuses on second language acquisition (SLA) (Brecht, Davidson, \& Ginsberg, 1995; Carson \& Longhini, 2002; DeKeyser, 1991; Freed, 1995; Freed, 1998; Isabelli, 2000; Waldbaum, 1996; Wilkinson, 1995) or psychosocial development of participants (Carsello \& Creaser, 1976; Herman, 1996; Kauffman, Weaver, \& Weaver, 1992; Lathrop, 1999; Wortman, 2002). Some studies, while including a control group, have focused on participants in a single study abroad program, greatly limiting the generalizability of results (see, for example, McCabe, 1994).

Of the studies that attempt to measure longitudinal impact (Carlson, Burn, Useem, \& Yachimowicz, 1991; Cash, 1993; Dukes, Lockwood, Oliver, Pezalila, \& Wilker, 1994; McCombie, 1988), none included comparisons of programs abroad that differed by the language of instruction. One study of 181 undergraduates included a breakdown of results in certain areas by the language of the host country (Brown, 1998). Brown found that participants of programs in English-speaking countries had lower stress if they had visited the host country prior to study abroad and that among the students who studied in non-English-speaking countries, the students with more advanced language skills had an easier adjustment.

Of the research on study abroad program models, only one study included a control group and analyzed the data on the basis of whether the host country language was English or another one (Wortman, 2002). However, Wortman's 
study investigated only one outcome: students' openness to diversity. Respondents who studied in English-speaking countries $(n=41)$ showed an increase in openness to diversity following study abroad, whereas those who studied in non-English-speaking countries $(\mathrm{n}=58)$ showed no change.

Another study examined outcomes of two different types of study abroad programs that happen to be grouped by language of instruction and include a control group (Lathrop, 1999). In this study, students in direct enrollment/full immersion programs with English as the language of instruction showed more significant changes in the areas of career planning and academic autonomy than participants who studied in mixed English and target language "hybrid" programs or the control group. The English-taught group also experienced more significant changes in salubrious lifestyle than the control group. The participants of mixed-language "hybrid" programs showed more significant changes in the categories of tolerance and salubrious lifestyle than the control group. The study revealed an overall increase in educational involvement from both study abroad models.

However, Lathrop's study is limited to psychosocial development of participants as measured by pre-test and post-test questionnaires. Additionally, the five programs selected for the study reveal some limitations in generalizability as they represented only one length (semester-long programs) and the locations were limited. The programs examined were all in Western European countries.

The literature review revealed no empirical studies that correlated the language of instruction with longitudinal outcomes. More research is required to reveal the tangible, quantifiable outcomes of various study abroad language environments. Such data will assist the education abroad field in acquiring the necessary resources to play its vital role in the internationalization of American higher education.

\section{Study Design}

IES Abroad (IES) is a not-for-profit, academic consortium of over 140 U.S. colleges and universities. Since its founding in 1950 as the Institute for European Studies, IES has provided opportunities for over 60,000 U.S. college students to participate in 62 study abroad programs at 30 sites in 16 countries. In 1997, IES drew on its nearly 50 years of extensive assessment of study abroad programs to develop the IES Model Assessment Program (The IES MAP ${ }^{\odot}$ ), a set of guidelines to design and evaluate international education programs. The IES MAP influenced the design of a 1999 pilot survey (Akande \& Slawson, 2000). After reviewing the results of the pilot study, IES conducted a largescale survey in 2002 of 17,000 alumni of its programs offered between 1950 
and 1999 . The primary purpose of the study was to measure the longitudinal correlations between specific program features, including language of instruction, participation in internships/field study, housing choices, and duration of study, and a variety of outcome measures.

The 2002 IES Alumni Survey consisted of twenty-eight items, several of which had sub-questions (Norris \& Dwyer, 2005). The instrument measured student outcomes by asking respondents to rate, on a 5-point Likert scale, the impact of their study abroad experience on specific developmental measures. Additional questions queried respondents on specific activities since studying abroad. The 2002 IES Alumni Survey had an overall 25\% response rate $(3,723$ of the 14,800 alumni current addresses). Alumni from the 1980 s and 1990 s produced large response rates of $40 \%$ and $41 \%$, respectively. The survey yielded a representative sample by U.S. geographic regions, decade of participation in an IES study abroad program, and attendance across 25 IES academic programs in 14 countries. This response rate was sufficient to estimate statistical confidence at the $95 \%$ level.

The large sample size, high response rate, number of years of data, number of U.S. universities from which the students originated (over 500), and the wide range of program models, lengths, and locations make the study particularly unique, valuable, and difficult to replicate. The 2002 IES Alumni Survey offers a rare opportunity to compare statistically valid and reliable results of the sustainable impact of specific study abroad program components on participants.

However, the study design has its limitations. Alumni satisfaction surveys rely on self-reported data and participants' memories, which can be selective. The survey instrument is not a standardized questionnaire commonly utilized by other researchers. With no control group, the results can infer only correlation, but not causation. Given that the IES alumni pool represents 50 years of undergraduate study by students at over 500 U.S. colleges and universities, achieving a control group that is truly comparable with the experiment group would be difficult.

This article focuses on the outcomes of study abroad for three groups within the IES alumni survey: participants of IES programs taught solely in the nonEnglish host country language (L2), participants of IES programs with courses taught in the L2, as well as in English (Mixed L1/L2), and participants of IES programs taught exclusively in English (L1). This study presents and discusses the data in relation to the overall question: Does the language of instruction affect the longitudinal outcomes of studying abroad? Under this umbrella question, this article addresses five specific questions presented in the results section below. 


\section{Overview of the Three Language Populations}

The L2 group consisted of participants of eight programs in five countries spread over three continents. Each program was exclusively taught in the host country language (German, Spanish, or French) and offered study in regular courses in host country universities. Admission to these programs required a minimum of four or five semesters of college-level language instruction or the equivalent. There were 1,672 total responses from these programs, which represented $44.9 \%$ of the total survey response.

The Mixed L1/L2 group included participants of eight programs in seven countries across two continents. These programs included instruction in English and the host country language: Chinese, French, Italian, Russian, Japanese, or German. These programs required none to one year of language study prior to study abroad, but were open to students with more language background. Students enrolled in Mixed L1/L2 programs were required to take language courses as part of these programs, ordinarily beginning with a two- or threeweek intensive language program, followed by regular language classes during the semester. The semester language offerings varied from courses meeting four hours per week to courses meeting as many as twenty hours per week with more intensive study, for example in the Asian programs where mastery necessitates learning thousands of characters. Students could elect other courses taught in the language of the country when they had sufficient fluency in the language. Almost all students in Mixed L1/L2 programs chose to take part of their instruction in English. Full-year students were most likely to opt for several courses or a complete program in the target language during their second semester of study. A total of 1,479 responses were included in the mixed language group, totaling $39.7 \%$ of the survey responses.

Five programs in three countries on two continents comprised the English-language-only group (L1), with a total of 533 participants accounting for $14.3 \%$ of the survey respondents. Those students who were directly enrolled in English language universities had a broad choice of courses. Of the IES L1 program respondents, $96.5 \%$ studied in English-speaking countries.

Across all three language of instruction types, about $85 \%$ of IES participants studied in non-English-speaking countries - much greater than the national proportion of Americans studying abroad in L2 locales. (Appendix 1 shows the program locations.) All three groups in the survey constituted representative samples of the total alumni of those programs and ranged in size from $18 \%$ to $23 \%$ of each of the language type's population. Therefore, responses were not weighted. All of the language of instruction categories contained 
programs ranging in length from six weeks to an academic year. The L2 and Mixed L1/L2 programs have been offered from the beginning of IES programming. The first L1 program was established in 1968.

\section{Student Profile}

There were statistically significant differences in the demographic profile of each group. The L2 program respondents were $76 \%$ female $(n=1253)$ and $24 \%$ male $(n=404)$, Mixed L1/L2 program respondents were $67 \%$ female $(n=$ 969) and $33 \%$ male $(n=468)$, and L1 program respondents were $63 \%$ female $(n=332)$ and $37 \%$ male $(n=194)$. There was a statistically significant relationship between the gender of respondents and the type of language program $\left(\chi^{2}=41.198, d f=2, p<.001\right)$.

The choices students made prior to their IES experience varied by language program. The participants of L2 programs were more than twice as likely to have studied abroad prior to their IES experience than L1 students. Mixed L1/L2 students fell in the middle. The L2 students, followed by Mixed L1/L2 students, were the most likely to have been influenced by their desire to study abroad when choosing an American college (see Table 1). A statistically significant relationship existed between these variables.

Table 1. Academic Choices.

\begin{tabular}{|c|c|c|c|}
\hline & $\mathrm{L} 2$ & Mixed L1/L2 & L1 \\
\hline \multicolumn{4}{|l|}{ Pre-IES Academic Choices } \\
\hline $\begin{array}{l}\text { Studied abroad pre-IES } \\
\text { SA influenced college choice }\end{array}$ & $\begin{array}{l}24 \% \\
(n=395) \\
27 \% \\
(n=450)\end{array}$ & $\begin{array}{l}17 \% \\
(n=245) \\
20 \% \\
(n=287)\end{array}$ & $\begin{array}{l}11 \% \\
(n=59) \\
20 \% \\
(n=106)\end{array}$ \\
\hline $\begin{array}{l}\text { Term Studied Abroad } \\
\text { Full Year }\end{array}$ & $\begin{array}{l}34 \% \\
(n=568)\end{array}$ & $\begin{array}{l}31 \% \\
(n=443)\end{array}$ & $\begin{array}{l}26 \% \\
(n=136)\end{array}$ \\
\hline Fall Semester & $\begin{array}{l}29 \% \\
(n=484)\end{array}$ & $\begin{array}{l}34 \% \\
(n=487)\end{array}$ & $\begin{array}{l}34 \% \\
(n=178)\end{array}$ \\
\hline Spring Semester & $\begin{array}{l}30 \% \\
(n=494)\end{array}$ & $\begin{array}{l}33 \% \\
(n=479)\end{array}$ & $\begin{array}{l}32 \% \\
(n=169)\end{array}$ \\
\hline $\begin{array}{l}\text { Summer (6 weeks or longer) } \\
\text { Coursework }\end{array}$ & $\begin{array}{l}9 \% \\
(n=146)\end{array}$ & $\begin{array}{l}3 \% \\
(n=48)\end{array}$ & $\begin{array}{l}9 \% \\
(n=49)\end{array}$ \\
\hline $\begin{array}{l}\text { Took host university courses } \\
\text { Academic Internship }\end{array}$ & $\begin{array}{l}65 \% \\
(n=1093)\end{array}$ & $\begin{array}{l}31 \% \\
(n=422)\end{array}$ & $\begin{array}{l}65 \% \\
(n=343)\end{array}$ \\
\hline $\begin{array}{l}\text { Participated in an internship } \\
\text { Post-IES Academic Choices }\end{array}$ & $\begin{array}{l}11 \% \\
(n=186)\end{array}$ & $\begin{array}{l}25 \% \\
(n=362)\end{array}$ & $\begin{array}{l}18 \% \\
(n=97)\end{array}$ \\
\hline $\begin{array}{l}\text { Studied abroad again post- } \\
\text { IES }\end{array}$ & $\begin{array}{l}19 \% \\
(n=316)\end{array}$ & $\begin{array}{l}15 \% \\
(n=221)\end{array}$ & $\begin{array}{l}12 \% \\
(n=63)\end{array}$ \\
\hline
\end{tabular}

All of the data on this table are significant, with $p<.02$, 


\section{Resu I t s}

Nearly all of the data from this study was categorical, and thus presented in frequency tables (both percentages and frequencies). In order to explore the research questions considered by this article, we conducted a breakdown analysis to determine the correlations for the full range of dependent variables with the independent variables (language groups). This exploratory analysis allowed us to discern whether the language of instruction groups differed in respect to the outcomes - the impact of study abroad on academics, careers, further language study and usage, personal relationships, and intercultural awareness. Pearson Chi-square tests were run in order to determine which cross tabulations yielded statistically significant results at the .05 level.

\section{Academic Choices and Attainment}

Research Question 1: Are there salient differences in academic choices and attainment during and following study abroad when participants of the three language models are compared?

Participants of all three language program models studied abroad through an IES program anywhere from six weeks to a full academic year. Table 1 illustrates the differences in program length between the groups, which should be viewed in light of two considerations. First, the proportion of IES students studying abroad for a full year has been declining since the 1970s, in keeping with national trends. Second, there are few Mixed L1/L2 programs designed for the summer only. When cross-tabulated by language of instruction, both summer and full-year results were statistically significant at the level of $p<.01$.

In addition to choosing the length of study, most IES students have the choice of enrolling in host university courses while abroad. This academic choice yielded greater differences between the three language groups, with equal proportions of L2 and L1 students taking host university courses and about 50\% fewer Mixed L1/L2 students, who were least likely to have the language skills requisite to study at a local university.

The last academic choice that students had for their program abroad was to participate in an internship or field placement for academic credit. Incorporating internships and field experiences for academic credit into IES programs started in the 1970s, and participants with adequate language skills have been encouraged to take part in these opportunities. L2 programs required a high level of fluency in the target language. Students in Mixed L1/L2 programs whose target language skills were not sufficient for university study found 
internships and field experiences to be an alternative means for interaction with the local population. Twice as many Mixed L1/L2 students as L2 students elected this option, with L1 students falling right in the middle. The career section below discusses the impact of internship participation on alumni.

The pre-IES study abroad choices were mirrored by post-IES participation in study abroad programs (Table 1). Participants of L2 programs were most likely to study abroad again following their IES experience, followed by alumni of Mixed L1/L2 programs, and then those of L1 programs. These results were statistically significant $\left(\chi^{2}=16.589, d f=2, p<.001\right)$.

The IES survey included six questions on the impact of the IES study abroad experience on alumni academic choices; two yielded statistically significant results (Table 2). Almost all L2 alumni and nearly four-fifths of Mixed L1/L2 alumni agreed that their IES experience reinforced their commitment to foreign language study, a statistically significant result $\left(\chi^{2}=366.348, d f=8, p<.001\right.$.

Table 2. Impact of Study Abroad on Academic Choices.

A larger percentage of $\mathrm{L} 2$ program participants agreed with the statement

\begin{tabular}{llll}
\hline Table 2: & L2 & Mixed L1/L2 & L1 \\
\hline $\begin{array}{l}\text { Reinforced commitment } \\
\text { to foreign language }\end{array}$ & $94 \%$ & $79 \%$ & $63 \%$ \\
study & $(n=1485)$ & $(n=962)$ & $(n=117)$ \\
Influenced decision to & $68 \%$ & $59 \%$ & $59 \%$ \\
expand/change majors & $(n=802)$ & $(n=599)$ & $(n=196)$ \\
\hline
\end{tabular}

Results are statistically significant at the $p<.001$ level.

that studying abroad influenced the respondent's decision to expand or change academic majors; the percentage of positive responses from alumni of Mixed L1/L2 and L1 programs were equal $\left(\chi^{2}=32.641, d f=8, p<.001\right)$. A participant of IES's 1997-98 Berlin program commented on how his experience abroad turned his academic attention toward library science:

With the extra time I found on my hands in Berlin I decided to learn how to use the Staatsbibliothek, or National Library... The resources proved to be outstanding, and my experiences from the time I spent in the Staatsbibliothek now help me tremendously as a Master of Information and Library Science student here in the States. In fact, it was my contact with the library students at the Humboldt University in Berlin that led me first to consider a career in libraries!

\section{Language Acquisition Results}

Research Question 2: How do the language programs differ in terms of impact on language acquisition results of respondents? 
The IES Alumni Survey included four questions related to second language use and study. All four questions yielded statistically significant results (Table 3). No other area of impact (academic, career, personal development, or intercultural awareness) produced results that were all statistically significant.

Table 3. Second Language Use and Impact.

\begin{tabular}{|c|c|c|c|}
\hline & $\mathrm{L} 2$ & Mixed L1/L2 & L1 \\
\hline $\begin{array}{l}\text { Currently use any language other } \\
\text { than English on a regular basis } \\
\text { (more than once a month) }\end{array}$ & $\begin{array}{l}51 \% \\
(n=847)\end{array}$ & $\begin{array}{l}26 \% \\
(n=374)\end{array}$ & $\begin{array}{l}15 \% \\
(n=76)\end{array}$ \\
\hline $\begin{array}{l}\text { Reinforced commitment to } \\
\text { foreign language study }\end{array}$ & $\begin{array}{l}94 \% \\
(n=1485)\end{array}$ & $\begin{array}{l}79 \% \\
(n=962)\end{array}$ & $\begin{array}{l}63 \% \\
(n=117)\end{array}$ \\
\hline $\begin{array}{l}\text { Enhanced ability to speak a } \\
\text { language other than English } \\
\text { utilized in a workplace setting }\end{array}$ & $\begin{array}{l}78 \% \\
(n=1081)\end{array}$ & $\begin{array}{l}52 \% \\
(n=498)\end{array}$ & $\begin{array}{l}28 \% \\
(n=27)\end{array}$ \\
\hline $\begin{array}{l}\text { Opened up an interest/passion } \\
\text { for another language and/or } \\
\text { culture }\end{array}$ & $\begin{array}{l}66 \% \\
(n=1096)\end{array}$ & $\begin{array}{l}60 \% \\
(n=866)\end{array}$ & $\begin{array}{l}48 \% \\
(n=250)\end{array}$ \\
\hline
\end{tabular}

All of the data on this table are statistically significant at the $p<.001$ level.

The first language question asked of IES alumni was whether they use any language other than English on a regular basis. Results correlated strongly with the proportion of instruction in the second language that respondents received while abroad. The L2 group was twice as likely as the Mixed L1/L2 group, and more than three times as likely as the L1 group, still to use a second language on a regular basis $\left(\chi^{2}=323.182, d f=2, p<.001\right)$.

Second, respondents were asked whether the study abroad experience reinforced their commitment to foreign language study, as discussed in the academic impact section above. While the L2 and Mixed L1/L2 results are not surprising, the data from the L1 alumni is. Even though these students participated in programs taught solely in English, more than half of them agreed that their experience abroad reinforced their commitment to foreign language study. The following alumni comment illustrates the impact that studying in London had on an IES London Spring 1985 program participant's confidence and ability to navigate non-English-speaking countries, which later impacted her language acquisition and career path:

Before studying abroad with IES in London, the rest of the world was distant and frightening. Through my semester abroad followed by travel in Western and Eastern Europe, however, I learned to explore countries where the languages and cultures were alien and I had to figure out how to get around on my own while at the same time enjoying my travels. From that time onward it has been hard to keep me in the U.S. I have since 
lived and worked for nine years in China, Pakistan, Afghanistan and the United Arab Emirates and traveled to more than 35 countries. I now speak Pashtu, Chinese, and French at varying levels. None of this would have happened without the first step — studying in London.

Third, IES alumni were asked if their study abroad experience enhanced their ability to speak a language (other than English) that they have utilized in a workplace setting. Again, a statistically significant difference existed, with the L2 group lead with more than three-quarters responding affirmatively followed by over half of the Mixed L1/L2 and less than a third of the L1 groups $\left(\chi^{2}=327.778, d f=8, p<.001\right)$. One $\mathrm{L} 2$ respondent's comment illustrates this dramatically: "Spending a year abroad allowed me to continue to improve my Spanish language skills and it gave me the opportunity to travel extensively throughout Spain and the rest of Europe. I now work for Telefutura, a Spanishlanguage TV station, and I use Spanish on a daily basis."

Results for the fourth language question - whether the study abroad experience had opened up an interest/passion for another language and/or culture - corroborated with the other three language questions, yet yielded the smallest gap between the three groups. This relationship was still determined to be statistically significant $\left(\chi^{2}=56.118, d f=2, p<.001\right)$.

\section{Career Development Results}

Research Question 3: Does the language of instruction of these study abroad programs relate to variances in alumni career development?

The IES Alumni Survey contained eleven questions, one with eight subquestions, to measure the impact of studying abroad on the career development of respondents. The majority of career development questions yielded statistically significant correlations; most of these results are presented in Table 5.

Of the total survey respondents, $48 \%$ worked or volunteered in an international capacity following their IES study abroad experience. A greater proportion of L2 respondents developed global careers, followed by Mixed L1/L2 participants, and then L1 respondents (see Table 4). The L2 group lead in all eight areas of globally-oriented work, with four work sectors producing statistically significant correlations with the language of instruction. The L2 group was more likely to have worked for a non-U.S. government $\left(\chi^{2}=9.342, d f=\right.$ $2, p=.009)$; as a teacher/educator either in another country or in the United States with an international component, for example as a bilingual teacher $\left(\chi^{2}\right.$ 
$=83.867, d f=2, p<.001)$. as a volunteer for a non-profit agency or organization abroad or for a globally-oriented position for such an organization in the United States $\left(\chi^{2}=15.020, d f=2, p=.001\right)$, or in an international capacity in the private industry $\left(\chi^{2}=21.050, d f=2, p<.001\right)$.

Table 4. Career Development — Post-Study Abroad International Work by Sector.

\begin{tabular}{llll} 
& \multicolumn{1}{c}{ L2 } & \multicolumn{1}{c}{ Mixed L1/L2 } & \multicolumn{1}{c}{ L1 } \\
\hline Private Industry** & $24 \%$ & $21 \%$ & $14 \%$ \\
& $(n=391)$ & $(n=297)$ & $(n=74)$ \\
U.S. government & $5 \%$ & $5 \%$ & $4 \%$ \\
For any other & $(n=90)$ & $(n=72)$ & $(n=20)$ \\
government** & $3 \%$ & $2 \%$ & $1 \%$ \\
Non-profit/NGO & $(n=47)$ & $(n=21)$ & $(n=5)$ \\
& $9 \%$ & $7 \%$ & $8 \%$ \\
Teacher/educator** & $(n=154)$ & $(n=102)$ & $(n=41)$ \\
Volunteer for non-profit & $(n=325)$ & $(n=144)$ & $(n=36)$ \\
agency ${ }^{* *}$ & $(n=169)$ & $(n=114)$ & $(n=26)$ \\
Consultant & $5 \%$ & $4 \%$ & $5 \%$ \\
& $(n=85)$ & $(n=58)$ & $(n=24)$ \\
In any other way & $7 \%$ & $6 \%$ & $5 \%$ \\
& $(n=111)$ & $(n=84)$ & $(n=25)$ \\
\hline \hline Worked Internationally & $56 \%$ & $46 \%$ & $35 \%$ \\
(any of the above) $^{*}$ & $(n=940)$ & $(n=678)$ & $(n$ \\
& & & $184)$ \\
\hline
\end{tabular}

* Some respondents marked multiple categories.

** Statistically significant; $p<.001$

As noted in the academic items section above, the Mixed L1/L2 group had the highest rate of participation in academic internships and field placements. However, Table 5 shows that the L1 group was most likely to report that the internship/field placement assisted or influenced them in their careers $(\chi 2=$ $10.747, d f=2, p=.005)$. While there is no data in the IES Alumni Survey to explain this result, it may be that students who interned in L1 environments, and therefore faced no language barrier, were given more challenging responsibilities and opportunities related to their academic and/or career interests.

\section{Cultural and Personal Development Results}

Research Question 4: Are there significant differences in the cultural and personal development of respondents when compared by language of instruction?

Throughout the 50-year period of programming included in the survey, IES students have had a range of housing options available to them. These options vary with each program given the differences in availability of housing at the host universities and neighboring communities, host government 
Table 5. Other Career Development Factors.

\begin{tabular}{|c|c|c|c|}
\hline & L2 & Mixed L1/L2 & L1 \\
\hline $\begin{array}{l}\text { Participated in an } \\
\text { internship/field placement }\end{array}$ & $\begin{array}{l}11 \% \\
(n=186)\end{array}$ & $\begin{array}{l}25 \% \\
(n=362)\end{array}$ & $\begin{array}{l}18 \% \\
(n=97)\end{array}$ \\
\hline $\begin{array}{l}\text { The internship/field placement } \\
\text { assisted or influenced me in } \\
\text { my career }\end{array}$ & $\begin{array}{l}61 \% \\
(n=114)\end{array}$ & $\begin{array}{l}62 \% \\
(n=223)\end{array}$ & $\begin{array}{l}79 \% \\
(n=75)\end{array}$ \\
\hline $\begin{array}{l}\text { Ignited interest in career } \\
\text { direction I pursued }\end{array}$ & $\begin{array}{l}66 \% \\
(n=828)\end{array}$ & $\begin{array}{l}61 \% \\
(n=656)\end{array}$ & $\begin{array}{l}58 \% \\
(n=224)\end{array}$ \\
\hline $\begin{array}{l}\text { Enhanced my ability to speak a } \\
\text { language other than English } \\
\text { utilized in a workplace setting }\end{array}$ & $\begin{array}{l}78 \% \\
(n=1081)\end{array}$ & $\begin{array}{l}52 \% \\
(n=498)\end{array}$ & $\begin{array}{l}30 \% \\
(n=27)\end{array}$ \\
\hline $\begin{array}{l}\text { Allowed me to acquire a skill } \\
\text { set that influenced my career } \\
\text { path }\end{array}$ & $\begin{array}{l}78 \% \\
(n=1074)\end{array}$ & $\begin{array}{l}75 \% \\
(n=859)\end{array}$ & $\begin{array}{l}78 \% \\
(n=312)\end{array}$ \\
\hline $\begin{array}{l}\text { Influenced me to get a job } \\
\text { overseas }\end{array}$ & $\begin{array}{l}18 \% \\
(n=303)\end{array}$ & $\begin{array}{l}18 \% \\
(n=263)\end{array}$ & $\begin{array}{l}12 \% \\
(n=64)\end{array}$ \\
\hline
\end{tabular}

regulations regarding visiting student housing, local customs, etc. Of all three program types, L2 students were the most likely to participate in home stays $\left(\chi^{2}=1114.859, d f=10, p<.001\right)$. Table 6 illustrates that L2 students were more than twice as likely to live with host country nationals in any kind of arrangement than were L1 students.

\section{Table 6. Housing Choices and Maintained Contact with Host Country} Nationals.

\begin{tabular}{llll}
\hline & \multicolumn{1}{c}{ L2 } & Mixed L1/L2 & \multicolumn{1}{c}{ L1 } \\
\hline $\begin{array}{l}\text { Lived in home stay with a local } \\
\text { family or resident }\end{array}$ & $\begin{array}{l}76 \% \\
(n=1264)\end{array}$ & $\begin{array}{l}59 \% \\
(n=846)\end{array}$ & $\begin{array}{l}3 \% \\
(n=13)\end{array}$ \\
$\begin{array}{l}\text { Lived with host country peers in } \\
\text { dorm or apartment }\end{array}$ & $\begin{array}{l}13 \% \\
(n=210)\end{array}$ & $\begin{array}{l}11 \% \\
(n=151)\end{array}$ & $\begin{array}{l}34 \% \\
(n=179)\end{array}$ \\
$\begin{array}{l}\text { Lived with host country nationals (all } \\
\text { housing types) }\end{array}$ & $\begin{array}{l}89 \% \\
(n=1474)\end{array}$ & $\begin{array}{l}70 \% \\
(n=997)\end{array}$ & $\begin{array}{l}37 \% \\
(n=192)\end{array}$ \\
$\begin{array}{l}\text { Maintained contact with host country } \\
\text { nationals with whom shared housing }\end{array}$ & $\begin{array}{l}22 \% \\
(n=360)\end{array}$ & $\begin{array}{l}13 \% \\
(n=187)\end{array}$ & $(n=130)$ \\
\hline All of the data on this table are significant, with $p<.001$. &
\end{tabular}

The survey asked respondents whether they have maintained contact with host country nationals with whom they shared housing while abroad $\left(\chi^{2}=52.824\right.$, $d f=2, p<.001)$. The L1 group was the most likely to have retained such relations. This result is in stark contrast with the small percentage of L1 students that lived with locals — host families and peers. However, it reflects the much higher percentage of L1 students who lived with local peers. The high rate of continued contact with locals with whom L1 respondents lived, therefore, may demonstrate that study abroad alumni are more likely to maintain contact with host country peers, as opposed to host families. The finding may also be attributable to the lack of language barriers resulting in more substantive, lasting relationships. 
As Table 7 reveals, the cultural and personal development of respondents varied by language model in important ways that yielded statistically significant, strong relationships. L2 program respondents developed a greater interest/passion for another language and/or culture than the other groups $\left(\chi^{2}=\right.$ $56.118, d f=2, p<.001)$. Respondents who were alumni of Mixed L1/L2 programs were most likely to acquire a new and ongoing appreciation of the arts $\left(\chi^{2}=89.985, d f=8, p<.001\right)$. The Mixed L1/L2 group was also most likely to maintain contact with U.S. friends whom they met abroad $\left(\chi^{2}=7.245, d f\right.$ $=2, p=.027)$. This probably reflects the fact that it is more difficult for students who are not proficient in the local language to develop friendships with local students and therefore they spend a greater part of their time with other Americans while abroad. Although L1 program respondents were least likely to maintain contact with U.S. friends they met abroad, they developed longer lasting ties to host country nationals - not just those with whom they lived — than the Mixed L1/L2 group $\left(\chi^{2}=30.565, d f=2, p<.001\right)$. This result corresponds to the much higher percentage of L1 students who lived with host country peers and the higher rate of maintained friendships with host country nationals with whom L1 program participants lived (see Table 6).

Table 7. Cultural and Personal Development.

\begin{tabular}{|c|c|c|c|}
\hline & L2 & Mixed L1/L2 & L1 \\
\hline $\begin{array}{l}\text { Allowed me to better understand } \\
\text { my own cultural values and } \\
\text { biases) }\end{array}$ & $\begin{array}{l}98 \% \\
(n=1592)\end{array}$ & $\begin{array}{l}98 \% \\
(n=1388)\end{array}$ & $\begin{array}{l}97 \% \\
(n=497)\end{array}$ \\
\hline $\begin{array}{l}\text { Gave me a new and ongoing } \\
\text { appreciation of the arts }\end{array}$ & $\begin{array}{l}89 \% \\
(n=1419)\end{array}$ & $\begin{array}{l}94 \% \\
(n=1330)\end{array}$ & $\begin{array}{l}87 \% \\
(n=434)\end{array}$ \\
\hline $\begin{array}{l}\text { Continues to influence my } \\
\text { interaction with people from } \\
\text { different cultural backgrounds }\end{array}$ & $\begin{array}{l}94 \% \\
(n=1528)\end{array}$ & $\begin{array}{l}94 \% \\
(n=1325)\end{array}$ & $\begin{array}{l}91 \% \\
(n=460)\end{array}$ \\
\hline $\begin{array}{l}\text { Met U.S. friends with whom I } \\
\text { maintain contact }\end{array}$ & $\begin{array}{l}51 \% \\
(n=853)\end{array}$ & $\begin{array}{l}55 \% \\
(n=792)\end{array}$ & $\begin{array}{l}49 \% \\
(n=258)\end{array}$ \\
\hline $\begin{array}{l}\text { Met host country friends with } \\
\text { whom I maintain contact }\end{array}$ & $\begin{array}{l}27 \% \\
(n=456)\end{array}$ & $\begin{array}{l}19 \% \\
(n=267)\end{array}$ & $\begin{array}{l}25 \% \\
(n=134)\end{array}$ \\
\hline $\begin{array}{l}\text { Opened up an interest/passion } \\
\text { for another language and/or } \\
\text { culture }\end{array}$ & $\begin{array}{l}66 \% \\
(n=1096)\end{array}$ & $\begin{array}{l}60 \% \\
(n=866)\end{array}$ & $\begin{array}{l}48 \% \\
(n=250)\end{array}$ \\
\hline $\begin{array}{l}\text { Influenced me to explore other } \\
\text { cultures }\end{array}$ & $\begin{array}{l}64 \% \\
(n=1075)\end{array}$ & $\begin{array}{l}66 \% \\
(n=958)\end{array}$ & $\begin{array}{l}60 \% \\
(n=313)\end{array}$ \\
\hline $\begin{array}{l}\text { Revisited the city or country } \\
\text { where I studied one or more } \\
\text { times after studying abroad }\end{array}$ & $\begin{array}{l}56 \% \\
(n=937)\end{array}$ & $\begin{array}{l}45 \% \\
(n=651)\end{array}$ & $\begin{array}{l}56 \% \\
(n=297)\end{array}$ \\
\hline
\end{tabular}

\section{Consistencies}

Research Question 5: What do the similarities between programs taught in different languages tell us about the universal impact of study abroad? 
Results from the IES Alumni Survey demonstrate many noteworthy distinctions between the outcomes of participation in L2, Mixed L1/L2, and L1 programs. The majority of the IES survey results (55\%) comparing responses from alumni of L2, Mixed L1/L2, and L1 programs yielded statistically insignificant data $(p>.05)$, which tells another side to the education abroad impact story. These data are useful in demonstrating the consistent impact of studying abroad, regardless of the program's language of instruction. All three language models yielded similar, statistically insignificant results for two-thirds of the academic outcomes, two-fifths of the career development measures, and twothirds of the cultural and personal development outcomes.

Overall, the statistically insignificant academic outcomes data presented in Table 8 clearly illustrate the positive educational impact that studying abroad had on the majority of survey respondents. In particular, the high percentage of respondents who indicated that study abroad enhanced their interest in academic study is noteworthy.

Table 8 shows that the statistically insignificant career development outcomes of L2, Mixed L1/L2, and L1. The respondents were about equally likely to develop professional contacts abroad or to be influenced to work for a multinational organization in the United States. Several findings presented in Table 4 echo this, with nearly equal proportions of the L2, Mixed L1/L2, and L1 respondents working in an international capacity for the U.S. government, a non-profit or NGO, or as a consultant. Table 8 also shows that of those who participated in internships, similar percentages felt that that experience shaped their career choice. Similar proportions of all three groups reported that they changed career plans as a result of studying abroad.

The universally felt positive impact of studying abroad is clearly illustrated, but there are no statistically significant differences in results between the three language models (see Table 9). A minimum of $94 \%$ of the L2, Mixed L1/L2, and L1 groups reported being most strongly affected by studying abroad in the following areas, listed by degree of impact: 1) enabled me to learn something new about myself 2) served as a catalyst for increased maturity, 3) increased my self-confidence; and 4) continues to influence my perspective on how I view the world. Close behind were these statements, which at least $85 \%$ of respondents of all three groups agreed to, listed in order of greatest impact: 5) influenced me to seek out a greater diversity of friends; 6) enabled me to tolerate ambiguity; and 7) continues to influence my political and social awareness.

The first four cultural and personal development measures listed above are extremely noteworthy, in that they represent four of the five questions on 
Table 8. Academic and Career-Related Consistencies.*

\begin{tabular}{|c|c|c|c|}
\hline & L2 & Mixed L1/L2 & L1 \\
\hline \multicolumn{4}{|l|}{ Academic Impact } \\
\hline $\begin{array}{l}\text { Enhanced interest in } \\
\text { academic study } \\
\text { Created interest in lifelong } \\
\text { learning } \\
\text { Influenced subsequent } \\
\text { educational experiences } \\
\text { Influenced decision to go to } \\
\text { graduate school }\end{array}$ & $\begin{array}{l}80 \% \\
(n=1176) \\
79 \% \\
(n=1161) \\
88 \% \\
(n=1321) \\
64 \% \\
(n=648) \\
\end{array}$ & $\begin{array}{l}80 \% \\
(n=1014) \\
82 \% \\
(n=1066) \\
86 \% \\
(n=1099) \\
62 \% \\
(n=543) \\
\end{array}$ & $\begin{array}{l}83 \% \\
(n=382) \\
79 \% \\
(n=369) \\
89 \% \\
(n=421) \\
70 \% \\
(n=245)\end{array}$ \\
\hline \multicolumn{4}{|l|}{ Career Development } \\
\hline $\begin{array}{l}\text { Provided me an internship } \\
\text { experience that shaped my } \\
\text { career choices }\end{array}$ & $\begin{array}{l}48 \% \\
(n=252)\end{array}$ & $\begin{array}{l}50 \% \\
(n=289)\end{array}$ & $\begin{array}{l}56 \% \\
(n=93)\end{array}$ \\
\hline $\begin{array}{l}\text { Established relationships that } \\
\text { became professional contacts } \\
\text { Influenced me to work for a } \\
\text { multi-national organization in } \\
\text { the United States }\end{array}$ & $\begin{array}{l}4 \% \\
(n=68) \\
15 \% \\
(n=253)\end{array}$ & $\begin{array}{l}5 \% \\
(n=80) \\
14 \% \\
(n=203)\end{array}$ & $\begin{array}{l}6 \% \\
(n=32) \\
12 \% \\
(n=63)\end{array}$ \\
\hline Changed career plans & $\begin{array}{l}13 \% \\
(n=218)\end{array}$ & $\begin{array}{l}12 \% \\
(n=170)\end{array}$ & $\begin{array}{l}11 \% \\
(n=60)\end{array}$ \\
\hline
\end{tabular}

the entire IES Alumni Survey that yielded the highest percentages of favorable response across all three groups being the fifth, (see Table 7). Beyond these five questions, of all the statistically significant findings comparing the three language models, only one group responded at as high a level to one question; $94 \%$ of the L2 respondents agreed that studying abroad reinforced their commitment to foreign language study. These findings are interesting in light of the trend mentioned in the introduction that language gain may not be the primary concern of most education abroad students in recent years. In the case of the L2 group - which represented $45 \%$ of the entire survey respondents - language gain was the sixth highest ranked outcome of studying abroad.

\section{Discus sion}

The findings yielded revealing answers to the five research questions posed in this study. To summarize, the three types of program by language of instruction correlated strongly with nineteen of the measures of impact on participants' academics, language study and usage, careers, and personal and cultural development. In nearly half of the cases, the L2 programs promoted the greatest impact; L2 tied for the highest response with Mixed L1/L2 or L2 programs on another $21 \%$ of impact questions that yielded statistically significant differences. Mixed L1/L2 programs followed behind L2 programs in terms of measures of impact, with L1 programs holding its ground on two questions and tying for the greatest impact on a third measure. By area of impact, academic and language results were dominated by L2 programs, whereas career 
and cultural and personal development outcomes revealed that all three program types were effective in different ways.

Table 9. Cultural and Personal Development Consistencies.*

\begin{tabular}{|c|c|c|c|}
\hline & L2 & Mixed L1/L2 & L1 \\
\hline $\begin{array}{l}\text { Influenced me to seek out a } \\
\text { greater diversity of friends }\end{array}$ & $\begin{array}{l}90 \% \\
(n=1427)\end{array}$ & $\begin{array}{l}91 \% \\
(n=1267)\end{array}$ & $\begin{array}{l}86 \% \\
(n=432)\end{array}$ \\
\hline Increased my self-confidence & $\begin{array}{l}96 \% \\
(n=1571)\end{array}$ & $\begin{array}{l}96 \% \\
(n=1361)\end{array}$ & $\begin{array}{l}96 \% \\
(n=494)\end{array}$ \\
\hline $\begin{array}{l}\text { Enabled me to tolerate } \\
\text { ambiguity }\end{array}$ & $\begin{array}{l}90 \% \\
(n=1344)\end{array}$ & $\begin{array}{l}89 \% \\
(n=1187)\end{array}$ & $\begin{array}{l}86 \% \\
(n=413)\end{array}$ \\
\hline $\begin{array}{l}\text { Enabled me to learn } \\
\text { something new about myself }\end{array}$ & $\begin{array}{l}99 \% \\
(n=1622)\end{array}$ & $\begin{array}{l}98 \% \\
(n=1396)\end{array}$ & $\begin{array}{l}98 \% \\
(n=506)\end{array}$ \\
\hline $\begin{array}{l}\text { Served as a catalyst for } \\
\text { increased maturity }\end{array}$ & $\begin{array}{l}97 \% \\
(n=1583)\end{array}$ & $\begin{array}{l}97 \% \\
(n=1369)\end{array}$ & $\begin{array}{l}96 \% \\
(n=494)\end{array}$ \\
\hline $\begin{array}{l}\text { Caused me to change or refine } \\
\text { my political and social views }\end{array}$ & $\begin{array}{l}84 \% \\
(n=1313)\end{array}$ & $\begin{array}{l}84 \% \\
(n=1151)\end{array}$ & $\begin{array}{l}84 \% \\
(n=413)\end{array}$ \\
\hline \multicolumn{4}{|l|}{ Continues to influence: } \\
\hline $\begin{array}{l}\text {...my political and social } \\
\text { awareness }\end{array}$ & $\begin{array}{l}87 \% \\
(n=1391)\end{array}$ & $\begin{array}{l}88 \% \\
(n=1221)\end{array}$ & $\begin{array}{l}86 \% \\
(n=436)\end{array}$ \\
\hline $\begin{array}{l}\text {...my participation in } \\
\text { community organizations }\end{array}$ & $\begin{array}{l}64 \% \\
(n=914)\end{array}$ & $\begin{array}{l}67 \% \\
(n=866)\end{array}$ & $\begin{array}{l}66 \% \\
(n=306)\end{array}$ \\
\hline $\begin{array}{l}\text {...my choices made in family } \\
\text { life }\end{array}$ & $\begin{array}{l}72 \% \\
(n=1042)\end{array}$ & $\begin{array}{l}74 \% \\
(n=956)\end{array}$ & $\begin{array}{l}72 \% \\
(n=326)\end{array}$ \\
\hline $\begin{array}{l}\text {...my perspective on how I } \\
\text { view the world }\end{array}$ & $\begin{array}{l}95 \% \\
(n=1549)\end{array}$ & $\begin{array}{l}95 \% \\
(n=1340)\end{array}$ & $\begin{array}{l}94 \% \\
(n=481)\end{array}$ \\
\hline $\begin{array}{l}\text { Met my spouse or life partner } \\
\text { there }\end{array}$ & $\begin{array}{l}4 \% \\
(n=69)\end{array}$ & $\begin{array}{l}5 \% \\
(n=73)\end{array}$ & $\begin{array}{l}4 \% \\
(n=19)\end{array}$ \\
\hline Sparked an interest in travel & $\begin{array}{l}73 \% \\
(n=1219)\end{array}$ & $\begin{array}{l}74 \% \\
(n=1076)\end{array}$ & $\begin{array}{l}77 \% \\
(n=404)\end{array}$ \\
\hline $\begin{array}{l}\text { Influenced me to develop a } \\
\text { more sophisticated way of } \\
\text { looking at the world }\end{array}$ & $\begin{array}{l}80 \% \\
(n=1340)\end{array}$ & $\begin{array}{l}83 \% \\
(n=1201)\end{array}$ & $\begin{array}{l}81 \% \\
(n=425)\end{array}$ \\
\hline
\end{tabular}

* All data on this table are statistically insignificant.

In pursuit of the salient differences in academic impact of the three types of programs by language of instruction, only a third of the academic impact findings yielded statistically significant results. While it is impressive that L2 programs proved to have a greater impact on participants in terms of changing or expanding their academic majors and increasing commitment to foreign language study, this finding was not surprising. L2 participants, who typically gain more foreign language credits while abroad than students in Mixed L1/L2 programs or L1 programs, are most likely to add a second major in the L2 upon return to their home university. Likewise, it is reasonable to expect that immersion in the target language environment and academic study of or at least using the host country language in local university courses would strengthen one's commitment to study the target language. More surprising is the unanticipated high response of alumni of English-taught programs that returned from studying abroad with a strengthened resolve to study foreign languages, and the similarly strong impact across all program types with respect to increased interest in academic, lifelong, and subsequent learning, including graduate 
school. In comparing the rates of participation in other study abroad programs prior to and following respondents' IES experiences, the IES program may have provided a slight equalizing impact. The disparity between L2, Mixed L1/L2, and L1 alumni participation rates in other education abroad programs pre-IES decreased by about half following their IES experience.

The language impact results stand above all other areas of influence, with all language-related questions yielding statistically significant, and often dramatic, differences between the three groups. All the language data demonstrated that respondents who had participated in L2 programs experienced the strongest impact in the areas of future language study and use, followed by Mixed L1/L2 participants, and finally L1 alumni. We anticipated these findings given the varying degrees by program type of second language study while abroad. What is remarkable is the fact that studying abroad reinforced the commitment to foreign language study in the majority of participants in all language models.

An earlier study of the career impact results from the 2002 IES Alumni Survey (Norris \& Gillespie, 2005) indicated a statistically significant relationship between the language of instruction (L1 vs. L2) and whether alumni developed global careers; alumni with international work histories were much more likely to have studied abroad on a program taught in a second language than in English. As such, we anticipated a strong relationship between most of the career outcomes and the three types of program by language of instruction. However, the lack of a clear trend in the statistically significant relationships between language of instruction and the career measures was unanticipated. L2 programs clearly yielded the strongest correlations on all academic and language questions with $p<.05$, they only held a clear first place in half of the career impact questions that produced such probability results. Two of these questions produced anticipated findings, correlating L2 programs with higher likelihood to develop an international career and to utilize an L2 in the workplace. L1 programs produced the strongest correlation with the impact of internships or field placements on participants' careers, suggesting that such outside the classroom learning experiences are maximized by one's ability to speak the host country language as a native speaker. This result may also explain L1 program alumni tying with L2 participants as most likely to credit their study abroad experience with acquiring a skill set that influenced their career paths. Mixed L1/L2 program alumni who developed international careers were most likely to attribute their study abroad experience with influencing them to get a job overseas, demonstrating that the study abroad experience is, for them, a greater turning point in deciding to work abroad than it is for L2 and L1 participants. 
The longitudinal data from the 2002 IES Alumni Survey clearly demonstrate the differences in impact that language of instruction has on the personal and cultural development of participants. These findings reveal a second area in which L2 programs do not dominate all the statistically significant relationships. Mixed L1/L2 program respondents indicated the greatest number of personal and cultural outcomes resulting from their IES experience: gaining an appreciation of the arts, making lasting U.S. friends, and exploring other cultures.

Given the interdisciplinary nature of these programs and the greater proportion of classes taken with participants of the IES Abroad program, these findings are not surprising. What was unanticipated is the fact that L1 programs yielded two statistically significant personal and cultural development results that were greater than the other two programs. First, L1 students were most likely to maintain contact with host country nationals with whom they had shared housing. This result may help explain the second result, that L1 alumni were most likely (albeit by only one tenth of a percentage) to travel back later to their IES host country; this result was in stark contrast to the L1 participants' being the least likely of all language program alumni to participate in other post-IES international experiences, specifically other study abroad programs or work abroad.

One perhaps unanticipated finding was the large number of impact questions $(55 \%)$ that did not yield statistically significant differences between the three language groups. Regardless of whether students participate in L2, Mixed L1/L2, or L1 programs, they benefit greatly from studying abroad in the areas of academic choices/attainment, language acquisition and use, career development, and personal/social growth and intercultural awareness.

The lack of statistically significant differences in impact between L2, Mixed L1/L2, and L1 models in most of the outcome measures of the categories of academic impact and cultural and personal development demonstrates the universal, holistic impact of studying abroad. It is a dramatic finding given the current assumptions found within the study abroad and SLA fields about what types of learning environments yield the greatest impact. This suggests that the popular assumption that students who participate in L1 programs do not gain as much from studying abroad as students who learn a second language may not hold. Numerous IES survey respondents representing all three language groups wrote in their comments that their experience abroad had "changed my life forever," "opened my mind to see the world as one community and brings hope in these troubled times," "taught me not only more about the [host] language, culture and history, but also independence, flexibility and confidence," etc. 


\section{Discussion of Each Type of Language Program Merits of target language-only programs}

The L2 model has a greater, more sustainable impact on every aspect of language acquisition and use, as well as academic impact, over the Mixed L1/L2 and L1 language models. In particular, L2 respondents reported much higher rates of continued use of a second language and of having gained language skills while abroad that they subsequently utilized in the workplace.

Nearly all L2 respondents testified that their IES study abroad experience reinforced their commitment to study a foreign language. This was echoed by the higher percentage of L2 students who reported that studying abroad opened up an interest/passion for another language and/or culture. The L2 group also showed a higher rate of influence by studying abroad in their decision to expand or change academic majors.

In addition, the L2 model exhibited a stronger effect on many aspects of students' career development. For example, L2 program participants were much more likely to develop an international career than Mixed L1/L2 or L1 participants. In spite of their lower participation rate in internships while abroad, L2 respondents were most likely to report that studying abroad ignited their interest in a career direction they pursued.

\section{Merits of mixed language programs}

Compared with the L2 and L1 models, the Mixed L1/L2 model has a greater, more sustainable impact on participants primarily in terms of cultural, personal, and career development. The Mixed L1/L2 model produced a greater increase in appreciation of the arts and an interest in exploring other cultures. On the social side, Mixed L1/L2 participants were most likely to continue friendships with U.S. friends met abroad.

Although fewer Mixed L1/L2 alumni than L2 alumni reported working in an international capacity either in the United States or overseas, they were equally likely to report that studying abroad influenced them to get a job overseas. Clearly, Mixed L1/L2 programs offer students without advanced L2 skills, the opportunity to study in another culture and language environment. Mixed L1/L2 participants gain a unique set of benefits from studying abroadbenefits which they might not have gained had they not ventured abroad.

\section{Merits of English language-only programs}

The IES research demonstrates that the English language-only model has a greater, more sustainable impact on participants primarily in terms of career 
development and lasting relationships with host-country nationals with whom they lived.

The data demonstrate that English-language taught programs cannot be written off as less of a worthwhile experience than those taught in a second language; rather these programs offer very significant, if different, benefits for the participants. The common language spoken between the American student and the people of the English-speaking host country can provide the study abroad participant opportunities to engage more deeply in the other culture.

\section{Further Research}

The IES Alumni Study establishes groundwork from which others may launch their studies on the outcomes of different study abroad language models. Additional research comparing the academic, language, career, personal/ social, and intercultural outcomes of each type of language model is needed to increase the generalizability of the findings. The IES consortium is comprised of selective/very selective Carnegie-classified colleges/universities. Therefore, research of student populations representing other higher education institution types - ideally across the same range of decades - would broaden the findings of this study. The IES study also did not differentiate students by type of college or by major field of interest. In future studies, it would be interesting to see whether these factors in students' background had an impact.

Educators and administrators also would benefit from additional longitudinal research on the impact of various study abroad language models compared with control groups. Such research would verify Waldbuam's (1996) case study, for example, which suggested the intensified development experienced by study abroad participants. Finally, more detailed research is needed to explore the impact of various language types when grouped into subcategories, such as the breakdown of English-taught programs into those in English-speaking countries and those in non-English-speaking countries and a comparison of students studying non-Western languages with students studying European languages.

\section{Conclusion}

Over a 50-year span, IES education abroad programs-whether taught exclusively or partially in a second language or only in English — have had a significant and lasting impact on participants. The data from the 2002 IES Alumni Survey illustrate that the three language models benefit students equally well in most areas of intercultural awareness, personal growth, academic choices, and career development. There are significant differences, however, in every aspect 
of second language commitment and use, with a predictably strong relationship between language of instruction and language impact. As well, there are notable differences in aspects of academic attainment, personal and social development, and the fostering of globally-oriented careers, with each type of language program producing unique merits. Overall, results of the IES Alumni Survey clearly demonstrate that study abroad enriches participants' lives well beyond the college years and in various ways, as reflected in this respondent comment:

My experience traveling abroad to Spain, taught me not only more about the Spanish language, culture and history, but also independence, flexibility and confidence. After college, I taught English in Mexico for two years. Teaching in Mexico has influenced my career today. I teach bilingually in San Diego, CA. Without studying abroad in Spain, I never would have had the courage to continue to explore other countries. I have now visited 12 countries in Europe and Central America thanks to the passion for traveling I gained during my foreign studies.

The implications of the 2002 IES Alumni Study for the SLA and study abroad fields are numerous. First, the data demonstrate the important role that education abroad plays in the higher education curriculum. Credited by IES respondents as providing the greatest learning and growth experience of all their college years, study abroad deserves increased attention from and resources of higher education policymakers and planners charged with developing and promoting various models of education abroad programs.

Second, the study supports the importance of academic and study abroad advisors in facilitating students' selection of programs that meet their academic, professional, and personal needs and goals. As study abroad opportunities increase and U.S. colleges and universities encourage more of their students to participate in education abroad, there is a greater need to understand the benefits of different study abroad learning environments. Each student needs to be matched appropriately to a program that meets his or her academic, cultural, linguistic and other goals, and that accounts for a student's preparation prior to studying abroad.

Third, the results point researchers in several directions of additional necessary research. The IES Alumni Survey provides a foundation for further research investigating the impact of different language learning environments on American study abroad participants, as well as the wide range of outcomes in a comparison of language students who study abroad and language students 
who do not take advantage of this opportunity but take advanced language courses in the United States.

The findings presented herein prove the rich benefits of study abroad programs, regardless of language of instruction, and lay an empirical foundation to continue to explore the multi-faceted, longitudinal outcomes of study abroad from the student's perspective. Given that most students do not go abroad with the primary goal of improving their language skills, this research makes a crucial contribution to the understanding of researchers, practitioners, and policymakers concerned with study abroad and SLA. While studies focused solely on linguistic improvements or gains in self-confidence are useful to the field, this study provides evidence to support our assertion that the personal, cultural, academic, career, and SLA goals of most study abroad students today will be realized regardless of their chosen program's language of instruction.

\section{A ck now l ed ge ments}

The authors wish to thank Dr. Mary Dwyer, President of IES Abroad, for her unflagging support and encouragement of this study. The authors are also grateful to Maggie Melin and Blake Ward, IES Abroad interns, for their assistance in conducting statistical tests of the data. Finally, we appreciate the participation of 3,723 alumni of IES Abroad programs in the 2002 IES Alumni Survey, without which we would have no findings to report.

\section{References}

Akande, Y., \& Slawson, C. (2000). A case study of 50 years of study abroad alumni. International Educator, 9(3), 12-16.

Bartini, M., Green, M. \& Hesel, R. A. (January 2008). College-bound students' interests in study abroad and other international learning activities: A special edition of studentPOLL. Washington, D.C.: American Council on Education (ACE), Art \& Science Group LLC, \& College Board.

Brecht, R. D., Davidson, D., \& Ginsberg, R. (1995). Predicting and measuring language gains in study abroad settings. In B. F. Freed (Ed.) Second language acquisition in a study abroad context (pp. 37-66). Amsterdam/Philadelphia: John Benjamins Publishing Company.

Brown, A. (1983). U.S. students abroad. In H. Jenkins (Ed.), Educating students from other nations (p. 67). San Francisco: Jossey-Bass.

Brown, H. E. (1998). Sojourner adjustment among undergraduate students: Relationships with locus of control and coping strategies. (Doctoral dissertation, The Claremont Graduate University, 1998). Digital Dissertations, 59/04, 1912. 
Carlson, J. S., Burn, B. B., Useem, J., \& Yachimowicz, D. (1990). Study abroad: The experience of American undergraduates. New York: Greenwood Press.

Carlson, J. S., Burn, B. B., Useem, J., \& Yachimowicz, D. (1991). The experience of American undergraduates in Western Europe and the United States. In E. G. Barber \& B. B. Burn (Eds.), Occasional papers on international educational exchange \#28, research series. New York: Council on International Educational Exchange.

Carsello, C., \& Creaser, J. (1976). How college students change during study abroad. College Student Journal, 10, 276-278.

Carson, J. G. \& Longhini, A. (2002). Focusing on learning styles and strategies: A diary study in an immersion setting. Language Learning, 52, 401-438.

Cash, R. W. (1993, May). Assessment of study abroad programs using surveys of student participants. Paper presented at the Association for Institutional Research Annual Forum, Chicago.

DeKeyser, R. (1991). Foreign language development during a semester abroad. In B. F. Freed (Ed.), Foreign language acquisition research and the classroom (pp. 104-119). Lexington, MA: D. C. Heath \& Co.

Dukes, R., Lockwood, E., Oliver, H., Pezalila, C., \& Wilker, C. (1994). A longitudinal study of a semester at sea voyage. Annals of Tourism Research, 21(3), 489-498.

Freed, B. F. (Ed.). (1995). Second language acquisition in a study abroad context. Philadelphia: John Benjamins Publishing Company.

Freed, B. F. (1998). An overview of issues and research in language learning in a study abroad setting. Frontiers: The Interdisciplinary Journal of Study Abroad, 4, 31-60.

Herman, N. B. (1996). The impact of study abroad experiences on the psychosocial development of college students (Doctoral dissertation, Ohio University, 1996). Digital Dissertations, DAI-A 57/11, 4659.

Institute for the International Education of Students (IES). (2003). The IES MAP for study abroad: Charting a course for quality. Chicago: Author.

Institute of International Education (IIE). (2008). Open doors 2007. New York: Author.

Isabelli, C. (2000). Motivation and extended interaction in the study abroad context: Factors in the development of Spanish language accuracy and communication skills. (Doctoral dissertation, University of Texas, Austin, 2000) Digital Dissertations, DAI-A 61/11, 4362.

Kauffman, M., Weaver, H., \& Weaver, T., (1992). Students abroad: Education for a global society. Yarmouth, ME: Intercultural Press. 
Koestler, J. (1986). A profile of foreign language majors who work, study, and travel abroad. The Modern Language Journal, 70(1), 21-27.

LaFranchi, H. (2003, August 13). Why more students are studying abroad: Reasons such as 'seeing the world' still prevail, but some students also want new views of the US role. Christian Science Monitor, USA section, p. 3.

Lathrop, B. J. J. (1999). The influence of study abroad programs on United States students' psychological development (Doctoral dissertation, University of Georgia, 1999). Digital Dissertations, DAI-A 60/11, 3917.

McCabe, L. J. (1994). The development of a global perspective during participation in Semester at Sea: A comparative global education program. Educational Review, 246, 275-286.

McCombie, R. P. (1988). Foreign study: An analysis of the long-term impact. (Doctoral dissertation, Loyola University of Chicago, 1988) Digital Dissertations, DAI-A 49/02, 569.

Norris, E. M., \& Dwyer, M. (2005). Testing assumptions: The impact of two study abroad program models. Frontiers: The Interdisciplinary Journal of Study Abroad, 11, 121-142.

Norris, E. M., \& Gillespie, J. (2005). Study abroad: Stepping stone to a successful international career. NACE Journal, 65(3), 30-36.

Opper, S., Teichler, U., \& Carlson, J. (1990). Impacts of study abroad programmes on students and graduates. Higher Education Policy Series, 11(2). London: Jessica Kingsley.

Peterson, D. (2003). The decision to study abroad: Contributing factors and implications for communication strategies. (Doctoral dissertation, Michigan State University, 2003) Digital Dissertations, DAI-A 64/05, 1450.

Wauldbaum, R. K. (1996). A case study of institutional and student outcomes of an educational exchange program: The University of Denver and the University of Bologna (Doctoral dissertation, University of Denver, 1996). Digital Dissertations, DAI-A 57/07, 2908.

Wilkinson, S. (1995) Foreign language conversation and the study abroad transition: A case study. (Doctoral dissertation, The Pennsylvania State University, 1995). Digital Dissertations, DAI-A 57/01, 140.

Wortman T. I. (2002). Psychosocial effects of studying abroad: Openness to diversity (Doctoral dissertation, Pennsylvania State University, 2002). Digital Dissertations, DAI-A 63/07, 2479. 
Appendix

IES Program Locations by Language of Instruction

\begin{tabular}{|l|l|l|}
\hline $\begin{array}{c}\text { Group 1 } \\
\text { Target Language } \\
\text { Only (L2) }\end{array}$ & $\begin{array}{c}\text { Group 2 } \\
\text { Mixed Target } \\
\text { Language/English } \\
\text { (Mixed L1/L2) }\end{array}$ & $\begin{array}{c}\text { Group 3 } \\
\text { English Only } \\
\text { (L1) }\end{array}$ \\
\hline Berlin, Germany & Beijing, China & \\
Freiburg, Germany & Dijon, France & Adelaide, Australia \\
La Plata, Argentina & Milan, Italy & Canberra, Australia \\
Madrid, Spain & Moscow, Russia & Durham, United Kingdom \\
Mexico City, Mexico & Nagoya, Japan & European Union, Freiburg \\
Nantes, France & Singapore & London, United Kingdom \\
Paris, France & Tokyo, Japan & \\
Salamanca, Spain & Vienna, Austria & \\
\hline
\end{tabular}

